\title{
Effect of Moringa Leaf Extract Spray on Sage (Salvia officinalis L.) Plant under Sandy Soil Conditions
}

\author{
Soha M. T. M. Abbas ${ }^{1}$; M. A. Zaglool ${ }^{2}$; E. A. E. El-Ghadban'; S. E. H. Abd El-Kareem ${ }^{2}$ and A. A. Waly \\ ${ }^{1}$ Medicinal and Aromatic Plants Research Department, Horticulture Research Institute, Agric. Res. Center, Giza, Egypt. \\ ${ }^{2}$ Horticulture Department, Faculty of Agriculture, Suez Canal University, 41522, Ismailia, Egypt.
}

Received: $15 / 8 / 2016$

\begin{abstract}
The present study was carried out at the Experimental Farm, Horticulture Department, Faculty of Agriculture, Suez Canal University during two successive seasons (2012 \& 2013). The objective was to study the effect of moringa leaf extract (MLE) spray at 0.0, 2.5, 5 and $10 \mathrm{gm} / \mathrm{L}$ on vegetative growth, yield, leaf area, oil percentage and the anatomical leaf structure of sage plant under sandy soil conditions. Spraying with MLE especially at highest concentration $(10 \mathrm{gm} / \mathrm{L})$ significantly increased the plant height, number of leaves, number of branches, yield and essential oil percentage in herb. In addition such treatment markedly increased the percentage of most essential oil component and enhancement the characteristic of leaf anatomy of sage plants.
\end{abstract}

Keywords: Moringa, sage, leaf extract, (MLE), Salvia officinalis L. (Sage) essential oil component and anatomical leaf structure.

\section{INTRODUCTION}

Sage (Salvia officinalis, L) plant is a perennial herb, rich in volatile oils which contain rosmarinic acid and $\alpha$ camphoraceous oil consisting of about $50 \%$ thujone. It has been used for different diseases including respiratory infection, menstrual difficulties and digestive complaints.

In Egypt, the total cultivated area of sage plants in 2016 reached about 220 fed. and produced about 1.59 ton of herbs/fed. (Ministry of Agric., 2016). However, we must expansion in medicinal and aromatic plants production because of our suitable climate conditions, abundance of employment and abundance of new reclaimed sandy soil.

Chemical fertilizers are very important source of plant nutrition, but they are expensive and represent a source of environmental pollution. Also, chemical fertilizers at high rates for long time may increase the dangerous effect of chemicals reside in plant tissues on the human health and animal consumers.

Thus, it has led growers of medicinal and aromatic plants in countries to use many plant extracts to improve and stimulate plant growth as well as increase the active ingredients instead of chemicals fertilization. Among these extracts as (MLE) which produced from the leaves of (Moringa olifera, Lam.) plants.

(MLE) has been identified contain macro \& micro nutrients, amino acids, plant growth hormones, vitamins, allele chemical a and anti- oxidants (Palada and Chang, 2003; Anwar et al., 2007; Basra et al., 2009; Pachauri and Flora 2011; Dhakar et al., 2013 and Hussain et al., 2013 )

Various plant extract such as moringa and yeast extracts have found wide use in increasing growth and yield of different kinds of plants, i.e. onions, soya, sorghum, coffee, melon, peanut, tea, chili, maize, rice, wheat, cowpea, tomato and bean (Price. 1985; Foidl et. al., 1996; Mathur, 2006; Fuglie, 2008; Phiri, 2010; Culver et al, 2012; Yasmeen et al., 2012; Culver et al., 2013; Muhamman et al., 2013).

Very little work have been done on the effect of moringa leaf extract on medicinal and aromatic plant such as Pradhu et al. (2010) on basil. However, the available data of the effect of (MLE) on vegetative growth, oil production and leaf anatomical structure of sage plant or other related species are not available in the literature.

Thus, the present work aimed to study the effect of foliar spraying with (MLE) on vegetative growth, yield and essential oil components as well as anatomical leaf structure of sage plants under sandy soil conditions.

\section{MATERIALS AND METHODS}

This work was carried out at the Experimental Nursery of the Department of Horticulture, Faculty of Agriculture Suez Canal University, Ismailia, Egypt during the two successive seasons of $(2012 \& 2013)$ to study the effect of foliar spraying with (MLE) on vegetative growth, yield, essential oil components and leaf anatomical structure of sage (Salvia officinalis, L.) plants under sandy soil conditions. The soil of the experimental was sandy with $\mathrm{pH}$ values of 7.22 and 7.52 and contained $28.00 \& 22.00 \mathrm{mg} \mathrm{kg-}^{-1}$ available N, $14.51 \& 20.50 \mathrm{mg} \mathrm{kg-}^{1}$ available P, $105 \& 139 \mathrm{mg} \mathrm{kg-}^{1}$ available $\mathrm{K}$ and $0.357 \& 0.288 \mathrm{mg} \mathrm{kg-}^{1}$ organic matter in the two seasons, respectively.

In early January of both seasons, the soil was divided into plots $(2.5 \times 2.5 \mathrm{~m})$ and amounted of cattle manure at the rate $25 \mathrm{~m}^{3} / \mathrm{fed}$. Cattle manure was mixed with the soil during the preparation process, five weeks before planting. The physical and chemical characteristics of cattle manure are presented in Table (1).

The plot containing 3 rows of $60 \mathrm{~cm}$ apart and $2 \mathrm{~m}$ length. Sage plants of (which previously prepared) by cutting were planted in $20^{\text {th }}$ and $7^{\text {th }}$ February in the first and second seasons, respectively. The spacing between plants was $30 \mathrm{~cm}$, since the number of plants was 3 in each row and 9 plants per plot.

Fresh leaves of moringa (Moringa olifera, Lam) were dried at room temperature then grounded into their powder and mixed with $80 \%$ ethanol to extract three times as suggested by (Makker and Becker, 1996). The 
suspension was stirred using rotatory evaporator under vacuum and kept in refrigerator until using. The drying extract was used at $2.5,5$ and $10 \mathrm{gm} / \mathrm{L}$ water and used for spraying of sage plants at three equal doses for every plant during the two growing seasons. The first addition was done one month after cultivations or after first cut of herbs, while the other addition was applied 15 days intervals after the first application, respectively. The control plants were sprayed with water.

Table (1): Physical and chemical characteristics of the cattle manure used for fertilization of sage plants during 2012 and 2013 seasons.

\begin{tabular}{|c|c|c|}
\hline Properties & First season & Second season \\
\hline EC dSm-1 & 0.85 & 1.09 \\
\hline pH & 7.11 & 7.66 \\
\hline \multicolumn{3}{|l|}{ Cations meq/L } \\
\hline $\mathrm{Ca}^{2}+$ & 4.00 & 5.00 \\
\hline $\mathbf{M g}^{2}+$ & 8.00 & 6.00 \\
\hline $\mathbf{N a}+$ & 17.00 & 12.0 \\
\hline $\mathbf{K}+$ & 22 & 15 \\
\hline \multicolumn{3}{|l|}{ Anions meq/L } \\
\hline Cl- & 20 & 17 \\
\hline HCO-3 & 6.00 & 7.00 \\
\hline $\mathrm{SO}_{4}$ & 25.0 & 14.0 \\
\hline $\mathrm{CO}_{3}{ }^{2-}$ & 0.0 & 0.0 \\
\hline Total N mgkg-1 & 1.63 & 1.07 \\
\hline Available N mgkg-1 & 254 & 294 \\
\hline Available $P$ mgkg-1 & 160 & 127 \\
\hline Available K mgkg- ${ }^{1}$ & 1040 & 1200 \\
\hline $\mathrm{C} / \mathrm{N}$ ratio & 12.58 & 16.14 \\
\hline Organic Carbon gkg-1 & 205 & 279 \\
\hline Organic Matter gkg- ${ }^{1}$ & 353 & 48.2 \\
\hline Moisture\% & 4.00 & 7.90 \\
\hline Fe mgkg-1 & 2388 & 2966 \\
\hline Cu mgkg-1 & 16.61 & 11.67 \\
\hline Mn mgkg-1 & 190.3 & 189.8 \\
\hline Zn mgkg-1 & 30.34 & 39.45 \\
\hline
\end{tabular}

So the experimental design was a randomized complete blocks, where the experiment involved 4 treatments with three replicates (plots).

The plants were irrigated whenever they needed and all of the cultural practices were followed as normal.
The harvesting process was taken place on $29^{\text {th }}$ May 2012, $15^{\text {th }}$ May 2013 for the first cut, and in $3^{\text {rd }}$ September 2012, $15^{\text {th }}$ August 2013 for the second cut, respectively. At the harvesting time, data were recorded concerting the vegetative growth presented in plant height $(\mathrm{cm})$, leaf number/plant, average of leaf area, and number of main branches/plant, fresh weight of herb/plant (gm) and dry weight of herb/plant (gm).

The essential oil percentage of each treatment of sage plants was determined in the fresh herb using water distillation method according to the British Pharmacopoeia (1963).

Essential oil constituents were analyzed [for the most effective treatments to essential oil production of sage plants $(10 \mathrm{gm} \mathrm{MLE} / \mathrm{L})$ and control treatment in the two cuts of the two studied seasons] using gas liquid chromatography (GLC) to determine the main constituents according to Hoftman (1967).

For anatomical study, leaf samples for the most effective treatments to essential oil production of sage plants $(10 \mathrm{gm} \mathrm{MLE} / \mathrm{L})$ and control treatment were taken in the second season at the time of the second cutting, killing and fixation in FAA solution $(10 \mathrm{ml}$ formalin+ $5 \mathrm{ml}$ glacial acetic acid $+50 \mathrm{ml}$ ethyl alcohol $95 \%+35$ $\mathrm{ml}$ distilled water), dehydration, clearing with $\mathrm{n}$ - butyl alcohol series and embedded in pararaffin wax of 56$58^{\circ} \mathrm{c}$, using a rotary microtome, sections $(20 \mu)$ were cut and stained with safranin and light green before mounting in Canada balsam. Slides were examined microscopically and photomicrography (Nassar and ElSahhar, 1998).

Data were statistically analyzed with the analysis of variance using a computer statistical software SPSS program Version 12.0, (copy right $(2003$ for SPSS Inc., USA), was used for handling data. Results were displayed as the differences between the means of treatments and tested using modified L.S.D. The means were significantly different if the $\mathrm{P}$ value was $=0.5$ according to Snedecor and Cochran (1980).

\section{RESULTS AND DISCUSSION}

\section{Effect of Moringa Leaf Extract (MLE) on vegetative growth}

Plant height (cm): It is clear from Tables (2\&3) that all MLE treatments significantly increased plant height comparing to untreated one in both seasons. In addition, a gradual increase in plant height was induced as MLE rate increased. The higher rate of MLE (10 gm/L water) produced the tallest plants as 59.30-64.18 and 58.10$59.49 \mathrm{~cm}$ compared to control plants as 44.55- 47.34 and $43.70-44.48 \mathrm{~cm}$ in the first and second seasons, respectively.

The increase in plant height that occurs may be from (MLE) can be used to produce an effective plant growth, hormone and increasing yield by $25-30 \%$. In addition to the active substances is zeatin a plant hormone from the cytokinines group this foliar spray should be used other fertilizer, watering and sound agricultural practices (Fuglie, 2000).

Similar stimulative effect on plant height as result of MLE application have been reported by Pal et al. 
(1995), Chawla et al. (1988); Pezzuto and Park (2002) and Fuglie (2008).

\section{Number of leaves/plant:}

Data presented in Tables $(2 \& 3)$ indicated that the number of leaves per plant was increased by increasing the rates of MLE. The least mean number of leaves per plant $(46.25,48.58$ and $48.75,46.58)$ was produced from the untreated plants, while the higher numbers of leaves per plant as $(69.08 \& 75.33)$ in the first season and $(71.33 \& 73.83)$ in the second season were obtained with those treated by MLE at rate $(10 \mathrm{gm} / \mathrm{L})$. At the same time, the statistical differences between treatments were significant. The plants treated with the lower $(2.5$ $\mathrm{gm} / \mathrm{L}$ water) and medium $(5 \mathrm{gm} / \mathrm{L})$ rates of MLE produced $(60.33,66.42$ and $64.08,65.50)$ and $(64.75$, 69.67 and $67.83,70.00)$ leaves /plant in the two season, respectively.

The possible reason for this acceleration of growth might be due to the enriched content of moringa leaf extract of crude proteins (43.5\%) and growth promoting hormones, as auxis and cytokinins, Protein is essential for the formation of the protoplasm, while growth hormones favored rapid cell division, cell multiplication and enlargement (Makkar and Becker, 1996).

In this connection, Mathur (2006) Fuglie (2008) and Moyo et al. (2011) concluded that increasing MLE rate resulted in an increase in number of leaves per plant.

Average of leaf area $\left(\mathrm{cm}^{2}\right)$ :

Data from Tables $(2 \& 3)$ showed that MLE at all levels caused a significant decrease in leaf area of leaves than the check treatment in both seasons. Moreover, the two levels of MLE at ( $5 \& 10 \mathrm{gm} / \mathrm{L})$ had significant decrease effect than that lower level $(2.5$ $\mathrm{gm} / \mathrm{L})$.

This result disagree with Yasmeen et al. (2012) who's reported that applying MLE on wheat exhibits longer seasonal leaf area duration compared with the control.

It worth to mentioned that the decrement in such leaf area of sage plants mainly due to negative correlation between leaf area and both numbers of leaves and branches per plant.

\section{Number of main branches /plant:}

As shown in Tables $(2 \& 3)$ in both seasons, MLE generally had significant effect in number of branches per plant than control. In addition level of $10 \mathrm{gm} / \mathrm{L}$ exhibited a significant increase in number of branches per plant compared to $2.5 \mathrm{gm} / \mathrm{L}$ or control. In this regard, the number of main branches/were $(11.00 \&$ 10.17 - 9.66 \&9.66), with the low level, $(11.83,11.08$ and $11.77,10.44)$ and with medium level, $(12.27,11.89$ and $13.55,11.41)$ with high level when compared to $(7.66 \& 6.58-5.30 \& 6.72)$ with the control in the first and second seasons, respectively.

The increment of such parameter could be attributing to the role of nutrient element of MLE in cell division, which led to increasing the number of branches/plant. These results are in agreement with those finding reported by Foidl et al. (2001) and Phiri (2010) on rice plant.

Table (2): Effect of (MLE) on vegetative growth and oil percentage of two cuts of sage (Salvia officinalis L.) during first season $r+I r$ and its two cuts.

\begin{tabular}{|c|c|c|c|c|c|c|c|}
\hline $\begin{array}{l}\text { Moringa } \\
\text { leaf extract } \\
\text { treatment } \\
(\mathrm{gm} / \mathrm{L})\end{array}$ & $\begin{array}{l}\text { Plant } \\
\text { height } \\
\text { (cm) }\end{array}$ & $\begin{array}{c}\text { Number of } \\
\text { leaves } \\
\text { /plant }\end{array}$ & $\begin{array}{c}\text { Leaf area } \\
\quad\left(\mathrm{cm}^{2}\right)\end{array}$ & $\begin{array}{c}\text { Number of } \\
\text { main } \\
\text { branches } \\
\text { /plant }\end{array}$ & $\begin{array}{c}\text { Fresh } \\
\text { weight } \\
\text { of herb/ } \\
\text { plant (gm) }\end{array}$ & $\begin{array}{c}\text { Dry weight } \\
\text { of herb/ } \\
\text { plant (gm) }\end{array}$ & $\begin{array}{c}\text { Oil } \\
\text { percentage } \\
(\%) / 100 \\
(\text { gm) F.W. }\end{array}$ \\
\hline \multicolumn{8}{|c|}{ First cut of season (2012) } \\
\hline 0.0 & 44.55 & 46.25 & 7.38 & 7.66 & 26.34 & 17.57 & 1.27 \\
\hline 2.5 & 53.64 & 60.33 & 5.57 & 11.00 & 44.03 & 34.14 & 1.44 \\
\hline 5 & 56.17 & 64.75 & 4.71 & 11.83 & 48.17 & 37.33 & 1.51 \\
\hline 10 & 59.30 & 69.08 & 4.44 & 12.27 & 52.52 & 41.05 & 1.54 \\
\hline L.S.D 0.05 & 2.32 & 2.93 & 0.89 & 0.55 & 2.40 & 1.61 & 0.49 \\
\hline \multicolumn{8}{|c|}{ Second cut of season (2012) } \\
\hline 0.0 & 47.34 & 48.58 & 9.01 & 6.58 & 25.96 & 19.64 & 1.05 \\
\hline 2.5 & 58.84 & 66.42 & 6.38 & 10.17 & 41.47 & 34.14 & 1.42 \\
\hline 5 & 62.04 & 69.67 & 5.49 & 11.08 & 45.16 & 37.32 & 1.48 \\
\hline 10 & 64.18 & 75.33 & 5.01 & 11.89 & 51.33 & 43.21 & 1.51 \\
\hline L.S.D 0.05 & 1.79 & 3.07 & 0.39 & 0.62 & 2.31 & 2.28 & 0.19 \\
\hline
\end{tabular}


Table (3): Effect of moringa leaf extract (MLE) on vegetative growth and oil percentage of two cuts of sage (Salvia officinalis L.) during second season 2013 and its two cuts.

\begin{tabular}{|c|c|c|c|c|c|c|c|}
\hline $\begin{array}{l}\text { Moringa } \\
\text { leaf extract } \\
\text { treatment } \\
(\mathrm{gm} / \mathrm{L})\end{array}$ & $\begin{array}{l}\text { Plant } \\
\text { height } \\
\text { (cm) }\end{array}$ & $\begin{array}{c}\text { Number of } \\
\text { leaves } \\
\text { /plant }\end{array}$ & $\begin{array}{l}\text { Leaf area } \\
\quad\left(\mathrm{cm}^{2}\right)\end{array}$ & $\begin{array}{c}\text { Number of } \\
\text { main } \\
\text { branches } \\
\text { /plant }\end{array}$ & $\begin{array}{c}\text { Fresh } \\
\text { weight } \\
\text { of herb/ } \\
\text { plant (gm) }\end{array}$ & $\begin{array}{c}\text { Dry weight } \\
\text { of herb/ } \\
\text { plant(gm) }\end{array}$ & $\begin{array}{c}\text { Oil } \\
\text { percentage } \\
(\%) / 100 \\
(\text { gm }) \text { F.W. }\end{array}$ \\
\hline \multicolumn{8}{|c|}{ First cut of season (2013) } \\
\hline 0.0 & 43.70 & 48.75 & 7.40 & 5.30 & 25.78 & 19.47 & 1.12 \\
\hline 2.5 & 52.88 & 64.08 & 5.58 & 9.66 & 40.90 & 35.00 & 1.36 \\
\hline 5 & 55.77 & 67.83 & 5.10 & 11.77 & 44.79 & 41.93 & 1.39 \\
\hline 10 & 58.10 & 71.33 & 4.41 & 13.55 & 49.86 & 43.19 & 1.41 \\
\hline L.S.D 0.05 & 2.06 & 3.67 & 0.31 & 0.47 & 2.01 & 4.25 & 0.26 \\
\hline \multicolumn{8}{|c|}{ Second cut of season (2013) } \\
\hline 0.0 & 44.48 & 46.58 & 9.07 & 6.72 & 25.73 & 19.18 & 1.08 \\
\hline 2.5 & 55.47 & 65.50 & 5.78 & 9.66 & 45.80 & 27.34 & 1.34 \\
\hline 5 & 57.49 & 70.00 & 5.15 & 10.44 & 49.53 & 31.32 & 1.43 \\
\hline 10 & 59.49 & 73.83 & 4.64 & 11.41 & 52.62 & 45.22 & 1.52 \\
\hline L.S.D 0.05 & 2.16 & 2.51 & 0.23 & 0.55 & 2.36 & 2.45 & 0.14 \\
\hline
\end{tabular}

Fresh and dry weight of herb/plant (gm):

Data recorded in Tables (2 \& 3) clearly indicate that by increasing MLE rate, and dry weights of leaves /plant were increased as compared to control.

Moreover, the high rate $(10 \mathrm{gm} / \mathrm{L})$ recorded the heaviest fresh weight as 52.52, 51.33 and 49.86, 2.62 gm while the lowest values as 26.34, 25.96 and 25.78 , $25.73 \mathrm{gm}$ were obtained in the control for the first and second seasons, and their cuts, respectively.

This effect may be due to beneficial effect of MLE properties. In addition to supply the growing plants with the required micro and macronutrient elements. Naturally, these elements play important roles in the metabolic processes like photosynthesis, respiration and carbohydrate synthesis. In this respect (Culver et al., 2012) on different crops, found that MLE especially at high rates of moringa significantly increased fresh and dry weights of leaves/plant in comparison with control. However, the dry weight of herbs/plants fallowed the same pattern as the herb fresh weight.

\section{Essential oil percentage in the herb:}

Results in Tables $(2 \& 3)$ revealed that the all levels of MLE gradually increased essential oil percentage in both seasons. These increments were statistically significant compared to untreated plants, except the lower concentration of MLE at $2.5 \mathrm{gm} / \mathrm{L}$ for the first cut in the two studied seasons. The most effective treatments were the medium and higher concentrations
(5 \& $10 \mathrm{gm} / \mathrm{L}$ ). Likewise, the highest values of the essential oil percentage were ranged between 1.54 and $1.41 \%$ compared to the control as $1.27,1.05$ and 1.12 , $1.08 \%$ in the both seasons.

The increase in the essential oil percentage when sage plants received the high level of MLE may be attributed to the higher energy in synthesis biochemical metabolites as result to applied MLE.

\section{Effect of MLE on essential oil components:}

It is clear from Tables $(4 \& 5)$ that the main components separated from sage essential oil were $\alpha$ pinene, camphene, $\beta$-pinene, 1,8 cineloe, thyjone, terpinene 4-01, borneol and eugenol. In addition the major components of sage oil were 1,8 cineloe and thujone which presented about $60 \%$ from oil components.

It is clear also, the treatment of MLE at $10 \mathrm{mg} / \mathrm{L}$ markedly increased the percentage of $\alpha$ pinene, camphene, $\beta$ - pinene, 1,8 cineole and borneol in essential oil of sage plants for the two cuts in the two studied seasons than that of the control, except camphene for the second cut in the first season, $\beta$ pinene for the first cut in the second season and borneol for the second cut in the two season. However, weak decreasing trend in percentage of thujone, terpinene 401 and eugenol was noted due to MLE treatment in both cuts and in the two seasons than the control. 
Table (4): Effect of (MLE) on essential oil components (\%) on two cuts of Salvia officialis L. in seasons 2012, 2013.

\begin{tabular}{|c|c|c|c|c|c|c|c|c|}
\hline \multirow[t]{2}{*}{ Treatments } & \multicolumn{8}{|c|}{ Essential oil components (\%) } \\
\hline & $\begin{array}{c}\alpha- \\
\text { pinene }\end{array}$ & Camphene & $\begin{array}{c}\beta- \\
\text { Pinene }\end{array}$ & $\begin{array}{c}1,8 \\
\text { cineole }\end{array}$ & Thujone & $\begin{array}{c}\text { Terpinene- } \\
\text { 4-01 }\end{array}$ & Borneol & Eugenol \\
\hline & \multicolumn{8}{|c|}{ First season } \\
\hline Control & 2.92 & 4.31 & 4.80 & 27.32 & 24.13 & 7.72 & 2.91 & 6.69 \\
\hline \multirow[t]{2}{*}{$\begin{array}{l}10 \mathrm{gm} \\
\text { MLE }\end{array}$} & 5.15 & 9.33 & 7.63 & 35.45 & 21.98 & 1.02 & 4.75 & 5.34 \\
\hline & \multicolumn{8}{|c|}{ Second season } \\
\hline Control & 1.05 & 5.06 & 7.37 & 32.83 & 21.46 & 4.77 & 3.67 & 4.87 \\
\hline $\begin{array}{l}10 \mathrm{gm} \\
\text { MLE }\end{array}$ & 4.90 & 6.30 & 8.32 & 36.25 & 17.31 & 5.15 & 3.71 & 6.35 \\
\hline
\end{tabular}

Table (5): Effect of moringa leaf extract(MLE) on essential oil components (\%) of Salvia officinalis L. in the seasons of 2012 and 2013.

\begin{tabular}{|c|c|c|c|c|c|c|c|c|}
\hline \multirow{2}{*}{ Treatments } & \multicolumn{8}{|c|}{ Essential oil components (\%) } \\
\hline & $\begin{array}{c}\alpha- \\
\text { pinene }\end{array}$ & Camphene & $\begin{array}{c}\beta- \\
\text { Pinene }\end{array}$ & $\begin{array}{c}1,8 \\
\text { cineole }\end{array}$ & Thujone & $\begin{array}{c}\text { Terpinene-4- } \\
01\end{array}$ & Borneol & Eugenol \\
\hline & \multicolumn{8}{|c|}{ First season } \\
\hline Control & 3.76 & 5.92 & 8.46 & 30.72 & 26.99 & 6.49 & 2.01 & 6.62 \\
\hline \multirow[t]{2}{*}{10 gm MLE } & 4.60 & 7.03 & 8.81 & 36.06 & 25.44 & 5.53 & 1.27 & 4.77 \\
\hline & \multicolumn{8}{|c|}{ Second season } \\
\hline Control & 4.56 & 7.92 & 9.22 & 34.58 & 26.22 & 4.96 & 1.54 & 4.81 \\
\hline 10 gm MLE & 5.17 & 6.86 & 7.81 & 37.69 & 19.38 & 4.18 & 1.35 & 4.70 \\
\hline
\end{tabular}

Effect of moringa leaf extract (MLE) on anatomical leaf structure of sage plant:

It is obvious from Table (6) and Fig. (1) That foliar application of sage plants with 10gm (MLE)/L increased the thickness of leaf blade, palisade tissue, spongy tissue and mesophyll tissue by $36.9,49.4,116.8$ and $32.3 \%$, respectively, more than the control. In addition, vascular bundle of midvein was slightly increased in size as a result of spraying with MLE. The increament was mainly due to slight increament in width $(+9.2 \%)$ and slight decreament in Length ($11.2 \%$ ) as compared to the control.

The obtained results indicated that the increase in vascular bundle due to such application was accompanied with the increment in length and width of xylem and width of phloem tissues which were 6.3, 8.0 and $5.9 \%$ over the control, respectively. However, phloem length was decreased by $6.2 \%$ in this respect. Likewise, MLE at $10 \mathrm{gm} / \mathrm{L}$ increased both number of xylem arm/ midvein bundle and xylem vessels arm by 2.2 and $9.4 \%$ more than the control, respectively.

The increment in anatomical structure in leaf of sage plants treated with MLE could be attributed to their composition which involved to amino acids, vitamins, protein and mineral nutrition which act to stimulate many biological processes in cluding cell division and enlargement. However, no available data was found in the literatures in this respect. 
Table (6): Effect of (MLE) at $10 \mathrm{gm} / \mathrm{L}$ on anatomical structure of sage leaf plant (means of three sections from three specimens).

\begin{tabular}{|c|c|c|c|}
\hline \multirow{2}{*}{ Anatomical structure } & \multicolumn{3}{|c|}{ Treatments } \\
\hline & Control & 40ml (ALE) /L & $\pm \%$ to control \\
\hline Thickness of blade $(\mu \mathrm{m})$ & 201.4 & 275.8 & +36.9 \\
\hline Thickness of palisade tissue $(\mu \mathrm{m})$ & 103.7 & 154.9 & +49.4 \\
\hline Thickness of spongy tissue $(\mu \mathrm{m})$ & 49.3 & 106.9 & +116.8 \\
\hline Thickness mesophyll tissue $(\mu \mathrm{m})$ & 162.8 & 215.3 & +32.3 \\
\hline Thickness of midvein $(\mu \mathrm{m})$ & 632.5 & 610.7 & -3.5 \\
\hline Length of vascular bundle ( $\mu \mathrm{m})$ & 271.2 & 240.9 & -11.2 \\
\hline Width of vascular bundle $(\mu \mathrm{m})$ & 359.1 & 392.1 & +9.2 \\
\hline Length of xylem tissue $(\mu \mathrm{m})$ & 169.8 & 180.5 & +6.3 \\
\hline Width of xylem tissue $(\mu \mathrm{m})$ & 337.7 & 364.6 & +8.0 \\
\hline Length of phloem tissue $(\mu \mathrm{m})$ & 99.1 & 93.0 & -6.2 \\
\hline Width of phloem tissue $(\mu \mathrm{m})$ & 368.8 & 390.7 & +5.9 \\
\hline No. of xylem arm/midvein bundle & 27.7 & 28.3 & +2.2 \\
\hline No. of xylem vessels/ arm & 10.7 & 11.7 & +9.4 \\
\hline
\end{tabular}

A

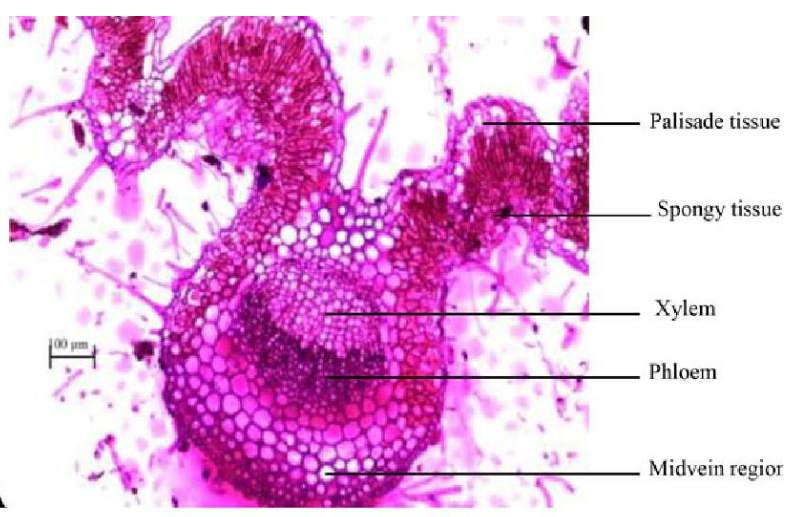

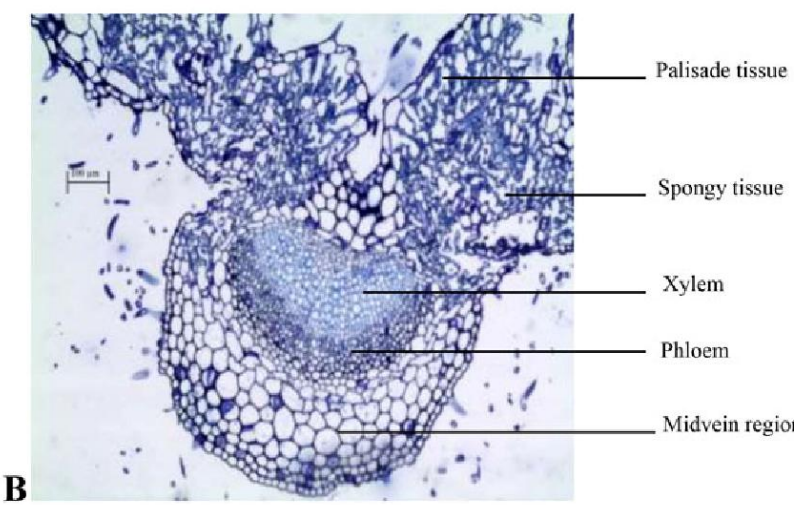

B

Fig. (1): Transverse sections through blade leaf of sage plant as affected by foliar application with moringa leave extract (MLE) at 10gm/L. A- From untreated plant (control). B- From plant sprayed with 10 gm (MLE)/L.

\section{REFERENCES}

Anwar, F., I. Saijd, A. Muhammad and H. G. Anwarul (2007). Moringa oleifera: A Food Plant with Multiple Medicinal Uses. Phytother. Res. 21, 1725.

Basra, S. M. A., M. Zahar, H. Rehman, A. Yasmin and H. Munir (2009): Evaluating the response of sorghum and moringa leaf water extract on seedling growth in hybrid maize applied through root media. In: Proceedings of the International Conference on Sustainable Food Grain
Production: Challenges and Opportunities. University of Agri. Faisalabad, Pakistan, pp. 23.

British Pharmacopeia (1963). Determination of Volatile Oils in Drugs the Pharmaceutical Press, 17 Bloomsbury Square, London, and WCI.

Chawla, S., A. Saxena and S. Seshadri (1988). In vitro availability of iron in various green leafy vegetables. J. Sci. Food Agric., 46:125-127.

Culver, M., T. Fanuel and C. A. Zvenhamo (2012). Effect of Moringa oleifera leaf aqueous extract on growth and yield of Rape and Cabbage. Afric. J. Biotech. 11(73): 13796-13800. 
Culver, M., T. Fanuel and C. A. Zvenhamo (2013). Effect of Moringa oleifera extract on growth and yield of maize and common beans. Greener, J. Agri. Sci., 3(1): 55-62.

Dhakar, C. R., S. D. Maurya, B. K. Pooniya, N. Bairwa and M. Gupta (2013). Moringa: The herbal gold to combat malnutrition. Chronicles of Young Scientists, 3(2): 119-125.

Foidl, N., H. P. S. Makkar and K. Becker (2001). The Potential of Moringa oleifera for Agricultural and Industrial Uses. Dar Es-Salaam Oct. $20^{\text {th }}-$ Nov. $2^{\text {nd }}$.

Fuglie, L. (2000). ECHOs Technical note. biomasa@ibw.com.in

Fuglie, L. (2008). ECHOs Technical Site. New Uses of Moringa Studied in Nicaragua. Moringa Tree Information.

Hussain, M., M. Farooq, Basra M. A. Shahzad and Lee Dong-Jin (2013). Application of Moringa Allelopathy in Crop Sciences. Allelopathy, pp 469-483.

Hoftman, E. (1967). Chromatography. Reinhold publ. corp., 2nd ed., 208-515.

Mathur, B. (2006). Moringa for Cattle Fodder and Plant Growth. President, Trees for Life. 3006 W. St. Louis, Wichita, Ks, TVY. T-5129.

Makker, H. P. S. and K. Becker (1996). Nutritional value and anti nutritional components of whole and ethanol extracted of Moringa oleifera leaves. Anim. Feed Sci. Technol., 63: 211-228.

Muhamman, A. M., B. M. Auwalu, A. A. Manga and M. J. Jibrin (2013). Effects of aqueous extract of moringa (Moringa oleifera Lam.) and nitrogen rates on some physiological attributes and yield of tomato. (IJCEBS), 1(1): 67-74.

Ministry of Agriculture (2016). Bulletin of The Agricultural Statistics, Total area for medicinal, aromatic and cutting flower plants in A.R.E., Economic Affairs Sector Ministry of Agriculture and Land Reclamation, Arab Republic of Egypt.

Moyo, B., P. Masika, A. Hugo and V. Muchenje (2011). Nutritional characterization of moringa (Moringa oleifera Lam) leaves. Afr. J. Biotechnol., 10(60): 12925-12933.
Nassar, M. A. and K. F. EL-Sahhar (1998). Botanical Preparations and Microscopy (Microtechnique).Academic Bookshop, Dokki Giza, Egypt. 219 pp. (In Arabic).

Pachauri, V. and S. J. S. Flora (2011). moringa seed extract and the prevention of oxidative stress. Nuts \& seeds in Health and Disease prevention. 92: 775-779.

Palada, M. C. and L. C. Chang (2003): Suggested Cultural Practices for Moringa. AVRDC pub\# 03-545.

Pal, S., K. Mukherjee and P. B. Saha (1995): Studies on the antiulcer activity of Moringa oleifera leaf extract on gastric ulcer models in rats. Phytotheraphy Research, 9: 463-465.

Pezzuto, J. M. and E. J. Park (2002): Autoxidation and antioxidants. In: Swarbrick, J., Boylan, J.C. (Eds.), Encyclopedia of Pharmaceuticals Technology, Vol. 1, second ed. Marcel Dekker Inc., New York, pp. 97-113.

Phiri, C. (2010). Influence of Moringa oleifera leaf extracts on germination and early seedling development of major cereals. Agri. Bio. J of North American. (5), 1, 774-777.

Pradhu, M., R. A. Kumar and K. Rajamani (2010): Influence of Different organic substances on growth and herb yield of sacred basil (Ocimum Sanctum L.) Indian, J. Agric. Res., 1(44): 48-52.

Price, L. M. (1985): The Moringa Tree. ECHO, 17391 Durrance Rd., North Ft. Myers FL. Pauls K.P. and J.E. Thompson. 1982. Effects of Cytokinins and Antioxidants on the Susceptibility of Membranes to Ozone Damage Plant and Cell Physiology, 23: 821-832.

Price, L. M. (2007): The Moringa Tree. ECHO Technical Note. Web site www. Echonet . Org .

Snedecor, G. W. and W. G. Cochran (1980). Statistical Methods $7^{\text {th }}$ Edition. Iowa state univ. press. Amer. Iowa, U.S.A.

Yasmeen, A., S. M. A. Basra, A. Wahid and R. Ahmad (2012). Performance of Late sown wheat in response to foliar application of Moringa oleifera Lam. leaf extract. Chil. J. Agric. Res., 1(72): 9297.

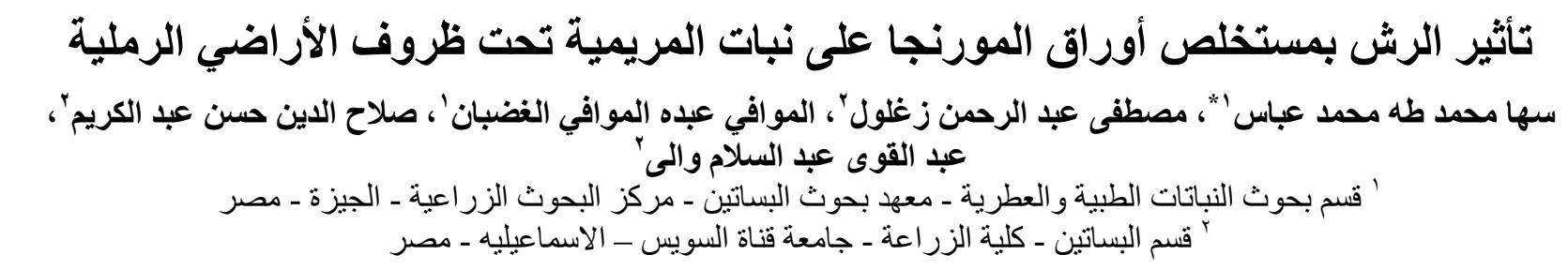

أجرى هدا البحث بمشتل نباتات الزينة بمزرعة كليه الزراعة جامعة قناة السويس بمحافظة الاسماعيليه جمهورية مصر العربية

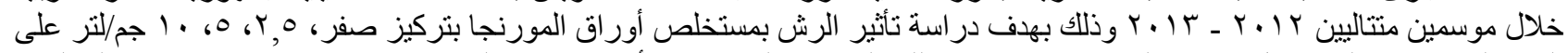

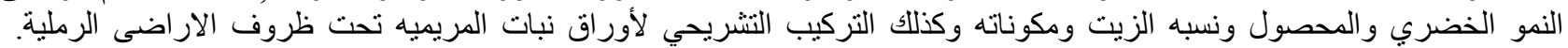

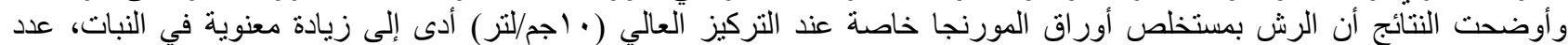

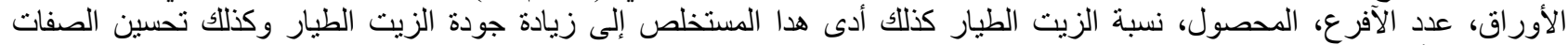
التشريحية للأور اق لنبات المريمية عن مثنيلتها في النباتات المبات المقارنة. 